\title{
Spontaneous Partitioning of Californium from Curium: Curious Cases from the Crystallization of Curium Coordination Com- plexes
}

\author{
Samantha K. Cary, ${ }^{1}$ Mark A. Silver, ${ }^{1}$ Guokui Liu, ${ }^{2}$ Jamie C. Wang, ${ }^{1}$ Justin A. Bogart, ${ }^{3}$ Jared T. \\ Stritzinger, ${ }^{1}$ Alexandra A. Arico, ${ }^{1}$ Kenneth Hanson, ${ }^{1}$ Eric J. Schelter, ${ }^{3}$ Thomas E. Albrecht- \\ Schmitt ${ }^{1 *}$ \\ ${ }^{1}$ Department of Chemistry and Biochemistry, Florida State University, Tallahassee, Florida 32306. \\ ${ }^{2}$ Chemical Sciences and Engineering Division, Argonne National Laboratory, Argonne, Illinois 60439, United \\ States. \\ ${ }^{3}$ P. Roy and Diana T. Vagelos Laboratories, Department of Chemistry, University of Pennsylvania, 231 South 34th \\ Street, Philadelphia, Pennsylvania 19104, United States.
}

\section{Email: albrecht-schmitt@chem.fsu.edu}

\section{Table of Contents}

Experimental Detail

Synthesis

X-ray diffractometer

UV-vis-NIR and photoluminescence spectroscopy

Excitation spectra

Liquid Scintillation Counting.

DFT Calculations. 


\section{Figures}

Figure S1. A photograph of crystals of $\left[\mathrm{Cm}(\mathrm{HDPA})\left(\mathrm{H}_{2} \mathrm{DPA}\right)\left(\mathrm{H}_{2} \mathrm{O}\right)_{2} \mathrm{Cl}\right] \mathrm{Cl} \cdot 2 \mathrm{H}_{2} \mathrm{O}$.

Figure S2. A view of the intermolecular contacts in $\left[\mathrm{Cm}(\mathrm{HDPA})\left(\mathrm{H}_{2} \mathrm{DPA}\right)\left(\mathrm{H}_{2} \mathrm{O}\right)_{2} \mathrm{Cl}\right] \mathrm{Cl} \cdot 2 \mathrm{H}_{2} \mathrm{O}$.

Figure S3. Excitation spectrum of $\left[\mathrm{Cm}(\mathrm{HDPA})\left(\mathrm{H}_{2} \mathrm{DPA}\right)\left(\mathrm{H}_{2} \mathrm{O}\right)_{2} \mathrm{Cl}\right] \mathrm{Cl} \cdot 2 \mathrm{H}_{2} \mathrm{O}$ from $320 \mathrm{~nm}$ to $410 \mathrm{~nm}$ monitored at $611 \mathrm{~nm}$.

Figure S4. Photoluminescence spectrum of a ${ }^{249} \mathrm{Cf}(\mathrm{HDPA})_{3}$ doped DPA sample (excitation at $420 \mathrm{~nm})$.

Figure S5. Overlay of ${ }^{249} \mathrm{Cf}(\mathrm{HDPA})_{3}$ doped DPA sample with spectrum acquired from a crystal of ${ }^{249} \mathrm{Cf}(\mathrm{HDPA})_{3}$.

Figure S6. Excitation spectrum of a ${ }^{249} \mathrm{Cf}(\mathrm{HDPA})_{3}$ doped DPA sample from $320 \mathrm{~nm}$ to $410 \mathrm{~nm}$ monitored at $525 \mathrm{~nm}$.

Figure S7. Renderings of the HOMO-2 (left) and LUMO (right) for the Cf(HDPA) 3 complex.

Figure S8. The $700-550 \mathrm{~cm}^{-1}$ region of the DFT predicted IR spectrum of the complex.

\section{Tables}

Table S1. Selected crystallographic information for the Cf-doped dipicolinic acid and $\left[\mathrm{Cm}(\mathrm{HDPA})\left(\mathrm{H}_{2} \mathrm{DPA}\right)\left(\mathrm{H}_{2} \mathrm{O}\right)_{2} \mathrm{Cl}\right] \mathrm{Cl} \cdot 2 \mathrm{H}_{2} \mathrm{O}(\mathbf{C m}-\mathbf{2})$.

Table S2. Optimized coordinates for $\mathrm{Cf}(\mathrm{HDPA})_{3}$. 
Experimental. Caution! ${ }^{248} \mathrm{Cm}\left(t_{1 / 2}=3.48 \times 10^{5} \mathrm{y}\right)$ represents a potential health risks owing to its $\alpha$ emission, and the emission from it's daughter, ${ }^{244} \mathrm{Pu}\left(t_{1 / 2}=8.08 \times 10^{7} \mathrm{y}\right)$, as well as undergoing spontaneous fission (which accounts for $8.3 \%$ of its decay) releasing a large flux of neutrons that can have a specific activity of $\sim 100 \mathrm{mRem} / \mathrm{hr}$ for the sample size used. ${ }^{249} \mathrm{Cf}\left(\mathrm{t}_{1 / 2}=351\right.$ $y$; specific activity $=4.1 \mathrm{Ci} / \mathrm{g})$ represent a serious external hazard because of its $\gamma(0.388 \mathrm{MeV})$ emission. ${ }^{249} \mathrm{Cf}$ decays to ${ }^{245} \mathrm{Cm}\left(t_{1 / 2}=8500 y\right)$, which also has a high specific activity. All studies with transuranium elements were conducted in a dedicated laboratory for transuranic elements. Specifically, the laboratory is equipped with HEPA filtered hoods and negative pressure glove boxes that are ported directly into the hoods. A series of different counters continually monitor radiation levels through out the laboratory. The laboratory is licensed by the State of Florida (an NRC-compliant state). All experiments were carried out with approved safety operating procedures. All free-flowing solids are worked with in glove boxes, and products are only examined when coated with either water or Krytox ${ }^{\circledR}$ oil and water. The ${ }^{249} \mathrm{Cf}$ sample used produces $1.7 \mathrm{R} / \mathrm{hr}$ at $40 \mathrm{~mm}$, and $\sim 10 \mathrm{R} / \mathrm{hr}$ at contact, and therefore represents a serious external hazard that required the experiments to be carefully choreographed to minimize exposure times. Thick lead sheets and long lead vests were used as much as possible to shield researchers from the remission.

Syntheses. $\mathrm{Cm}(\mathrm{HDPA})_{3} \cdot \mathrm{H}_{2} \mathrm{O}$ and $\left[\mathrm{Cm}(\mathrm{HDPA})\left(\mathrm{H}_{2} \mathrm{DPA}\right)\left(\mathrm{H}_{2} \mathrm{O}\right)_{2} \mathrm{Cl}\right] \mathrm{Cl} \cdot 2 \mathrm{H}_{2} \mathrm{O}$ were prepared as follows: $\mathrm{CmCl}_{3} \cdot \mathrm{nH}_{2} \mathrm{O}$ containing $5 \mathrm{mg}$ of ${ }^{248} \mathrm{Cm}$ was combined with a fivefold excess of DPA in $200 \mu \mathrm{L}$ of a 1:1 mixture of ethanol and water. The resultant reaction mixture was heated in a PTFE-lined Parr 4749 autoclave with a $10 \mathrm{~mL}$ internal volume for 4 hours at $150{ }^{\circ} \mathrm{C}$, and then slowly cooled to $23{ }^{\circ} \mathrm{C}$ over a twelve hour period. The furnace for heating the ${ }^{248} \mathrm{Cm}$ autoclave was located inside a negative-pressure glovebox, and was surrounded by thick lead sheets. The reactions result in the formation of nearly colorless crystals of $\mathrm{Cm}(\mathrm{HDPA})_{3} \cdot \mathrm{H}_{2} \mathrm{O}$ with a columnar habit. The crystals are pale yellow in bulk. The yield is ca. 50\%. The resultant mother liquor is pale yellow and was allowed to evaporate slowly by placing it in a stoppered vial with a small piece of weighing paper placed in between the vial and the stopper to allow the solvent mixture to evaporate. Peach-colored tablets of $\left[\mathrm{Cm}(\mathrm{HDPA})\left(\mathrm{H}_{2} \mathrm{DPA}\right)\left(\mathrm{H}_{2} \mathrm{O}\right)_{2} \mathrm{Cl}\right] \mathrm{Cl} \cdot 2 \mathrm{H}_{2} \mathrm{O}$ and large, absolutely colorless blocks of Cf-doped DPA formed during the evaporation. 
X-ray diffractometer. Single crystals of the $\left[\mathrm{Cm}(\mathrm{HDPA})\left(\mathrm{H}_{2} \mathrm{DPA}\right)\left(\mathrm{H}_{2} \mathrm{O}\right)_{2} \mathrm{Cl}\right] \mathrm{Cl} \cdot 2 \mathrm{H}_{2} \mathrm{O}$ were glued to Mitogen mounts with epoxy and optically aligned on a Bruker D8 Quest X-ray diffractometer using a digital camera. Initial intensity measurements were performed using a I $\mu \mathrm{S} X$-ray source $(\mathrm{MoK} \alpha, \lambda=0.71073 \AA)$ with high-brilliance and high-performance focusing multilayered optics. Standard software was used for determination of the unit cells and data collection control. The intensities of reflections of a sphere were collected by a combination of multiple sets of exposures (frames). Each set had a different $\varphi$ angle for the crystal and each exposure covered a range of $0.5^{\circ}$ in $\omega$. A variety of data collection strategies were employed including standard hemispheres, and more complex data sets with higher angles and greater degrees of redundancy. The SAINT software was used for data integration including Lorentz and polarization corrections. The structure was solved by direct methods and refined on $\mathrm{F}^{2}$ by full-matrix least squares techniques using the program suite SHELX. The hydrogen atoms on the ligands were all calculated using the standard riding model. The hydrogen atoms on the water molecules were located from the difference maps. Parameters $\mathrm{Cm}$ are not present in the SHELX software and have to be inputted manually. Crystallographic Information Files (CIF's) are available from the Cambridge Crystal Structure Database Center: CCDC 1404302.

UV-vis-NIR and photoluminescence spectroscopy. UV-vis-NIR and photoluminescence data was acquired from a single crystals using a Craic Technologies microspectrophotometer. Single crystals were placed on quartz slides under Krytox oil, and the data was collected from 300 to $1200 \mathrm{~nm}$. The exposure time was auto optimized by the Craic software. Photoluminescence data were acquired using the same microspectrophotometer with an excitation wavelength of $420 \mathrm{~nm}$ (Figure $3 \& 4$ ). Variable temperature measurements were achieved by using a Linkam cold temperature control stage.

Excitation spectra. were collected at room temperature using an Edinburgh FLS980 spectrometer. The sample, between two microscope slide coverlips was placed at a 45 degree angle relative to the excitation source and detector. Samples were excited using light output from a housed 450 W Xe lamp passed through a single grating (1800 1/mm, $250 \mathrm{~nm}$ blaze) Czerny-Turner mono- 
chromator (excitation 320-410 nm) and finally a $5 \mathrm{~nm}$ bandwidth slit. Emission from the sample was first passed through a $425 \mathrm{~nm}$ long-pass color filter, then a single grating $(1800 \mathrm{l} / \mathrm{mm}, 500$ $\mathrm{nm}$ blaze) Czerny-Turner monochromator (5 nm bandwidth) and finally detected at $525 \mathrm{~nm}$ and $611 \mathrm{~nm}$ by a peltier-cooled Hamamatsu R928 photomultiplier tube.

Liquid Scintillation Counting. Single crystals were dissolved nitric acid and mixed into PerkinElmer Optima Gold AB scintillation fluid. The samples were run on a Packard TRi-CARB 2900TR LSC liquid scintillation counter.

DFT Calculations. Electronic structure calculations were performed with Gaussian 09, Revision D.01. [Ref: Gaussian 09, Revision D.01, Frisch, M. J.; Trucks, G. W.; Schlegel, H. B.; Scuseria, G. E.; Robb, M. A.; Cheeseman, J. R.; Scalmani, G.; Barone, V.; Mennucci, B.; Petersson, G. A.; Nakatsuji, H.; Caricato, M.; Li, X.; Hratchian, H. P.; Izmaylov, A. F.; Bloino, J.; Zheng, G.; Sonnenberg, J. L.; Hada, M.; Ehara, M.; Toyota, K.; Fukuda, R.; Hasegawa, J.; Ishida, M.; Nakajima, T.; Honda, Y.; Kitao, O.; Nakai, H.; Vreven, T.; Montgomery, Jr., J. A.; Peralta, J. E.; Ogliaro, F.; Bearpark, M.; Heyd, J. J.; Brothers, E.; Kudin, K. N.; Staroverov, V. N.; Kobayashi, R.; Normand, J.; Raghavachari, K.; Rendell, A.; Burant, J. C.; Iyengar, S. S.; Tomasi, J.; Cossi, M.; Rega, N.; Millam, N. J.; Klene, M.; Knox, J. E.; Cross, J. B.; Bakken, V.; Adamo, C.; Jaramillo, J.; Gomperts, R.; Stratmann, R. E.; Yazyev, O.; Austin, A. J.; Cammi, R.; Pomelli, C.; Ochterski, J. W.; Martin, R. L.; Morokuma, K.; Zakrzewski, V. G.; Voth, G. A.; Salvador, P.; Dannenberg, J. J.; Dapprich, S.; Daniels, A. D.; Farkas, OM.; Foresman, J. B.; Ortiz, J. V.; Cioslowski, J.; Fox, D. J. Gaussian, Inc., Wallingford CT, 2009.] The B3LYP hybrid DFT method was employed with a 60-electron effective core potential for californium, with a published segmented natural orbital basis set incorporating quasi-relativistic effects, and the 6-31g* basis set for all other atoms. [Ref: a) Institute for Theoretical Chemistry, University of Cologne, http://www.tc.uni-koeln.de/PP/clickpse.en.html.; b) Cao, X.; Dolg, M.; Stoll, H.; J. Chem. Phys., 2003, 118, 487; c) Cao, X.; Dolg, M.; J. Molec. Struct., 2004, 673, 203.; d) Kuechle, W.; Dolg, M.; Stoll, H.; Preuss, H.; J. Chem. Phys., 1994, 100, 7535.] Solvent effects were modeled using a conductor-like polarizable continuum model (CPCM) and water as the solvent. [Ref: Cossi, M.; Rega, N.; Scalmani, G.; Barone, V. J. Comp. Chem.2003, 24, 669-681.] Geometry optimization was carried out starting from the coordinates of the crystal structure and frequency calculations were used to determine that the geometry was a minimum (no imaginary frequencies). Excited 
state TD-DFT calculations were performed on the optimized structure to determine the nature of the vertical transitions in the UV-Vis spectrum. Molecular orbitals were rendered with the Chemcraft v 1.6 program [Ref: Chemcraft, www.chemcraftprog.com.] 
Figure S1. A photograph of crystals of $\left[\mathrm{Cm}(\mathrm{HDPA})\left(\mathrm{H}_{2} \mathrm{DPA}\right)\left(\mathrm{H}_{2} \mathrm{O}\right)_{2} \mathrm{Cl}\right] \mathrm{Cl} \cdot 2 \mathrm{H}_{2} \mathrm{O}$.

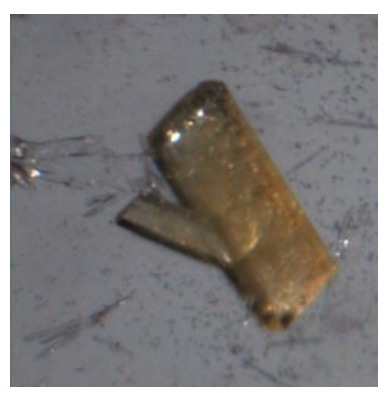

Figure S2. A view of the intermolecular contacts in $\left[\mathrm{Cm}(\mathrm{HDPA})\left(\mathrm{H}_{2} \mathrm{DPA}\right)\left(\mathrm{H}_{2} \mathrm{O}\right)_{2} \mathrm{Cl}\right] \mathrm{Cl} \cdot 2 \mathrm{H}_{2} \mathrm{O}$.

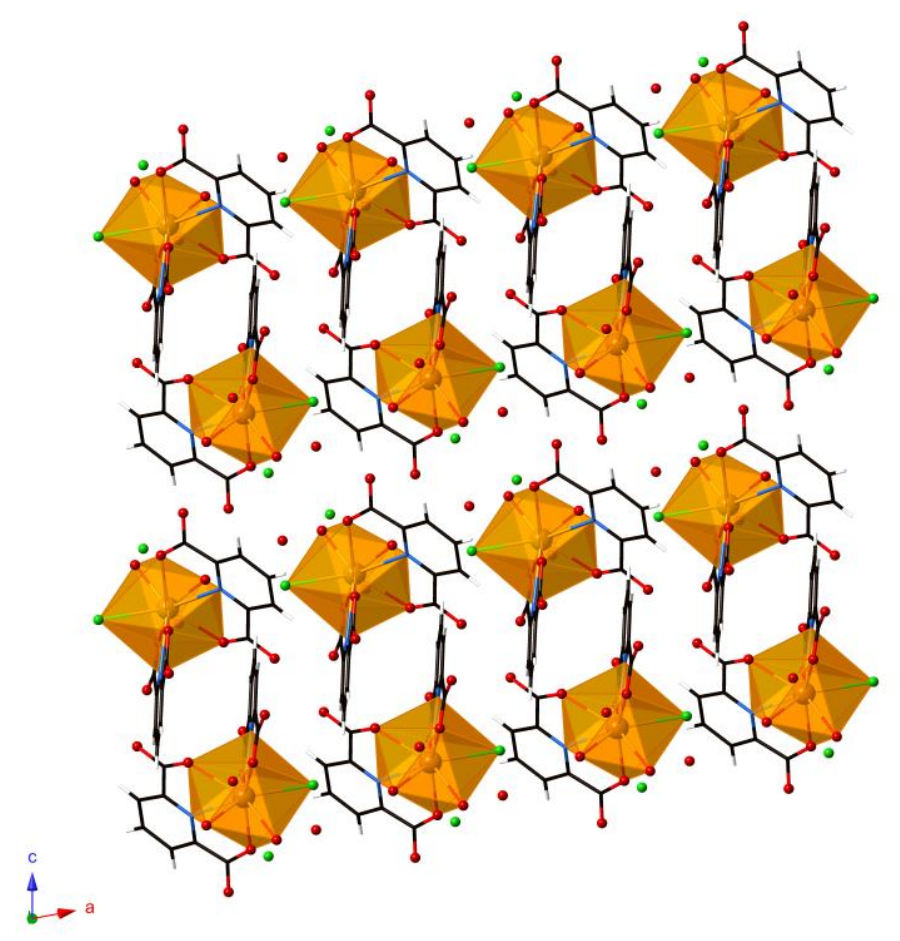


Figure S3. Excitation spectrum of $\left[\mathrm{Cm}(\mathrm{HDPA})\left(\mathrm{H}_{2} \mathrm{DPA}\right)\left(\mathrm{H}_{2} \mathrm{O}\right)_{2} \mathrm{Cl}\right] \mathrm{Cl} \cdot 2 \mathrm{H}_{2} \mathrm{O}$ from $320 \mathrm{~nm}$ to 410 $\mathrm{nm}$ monitored at $611 \mathrm{~nm}$.

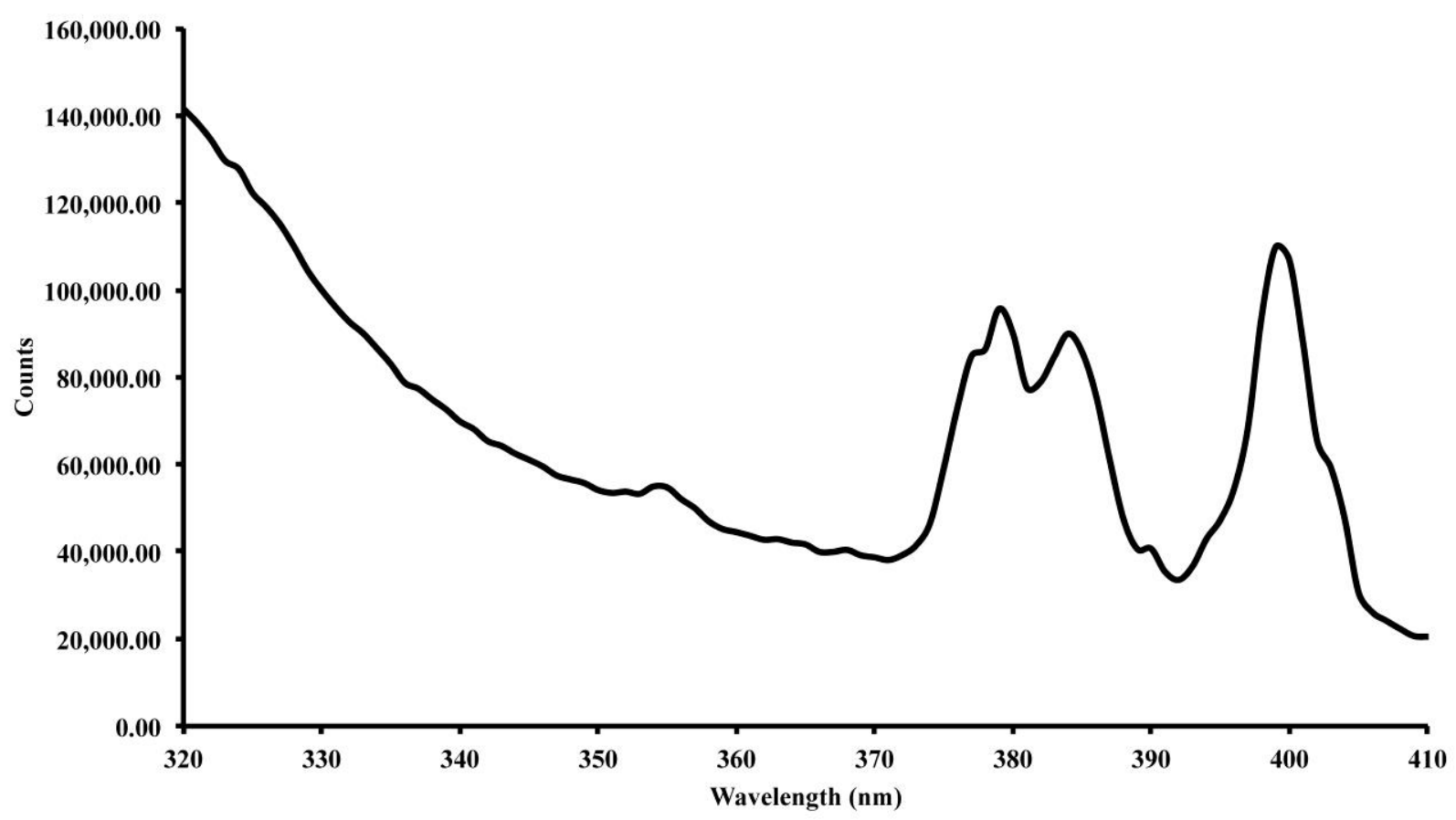

Figure S4. Photoluminescence spectrum of a ${ }^{249} \mathrm{Cf}(\mathrm{HDPA})_{3}$ doped DPA sample (excitation at $420 \mathrm{~nm})$.

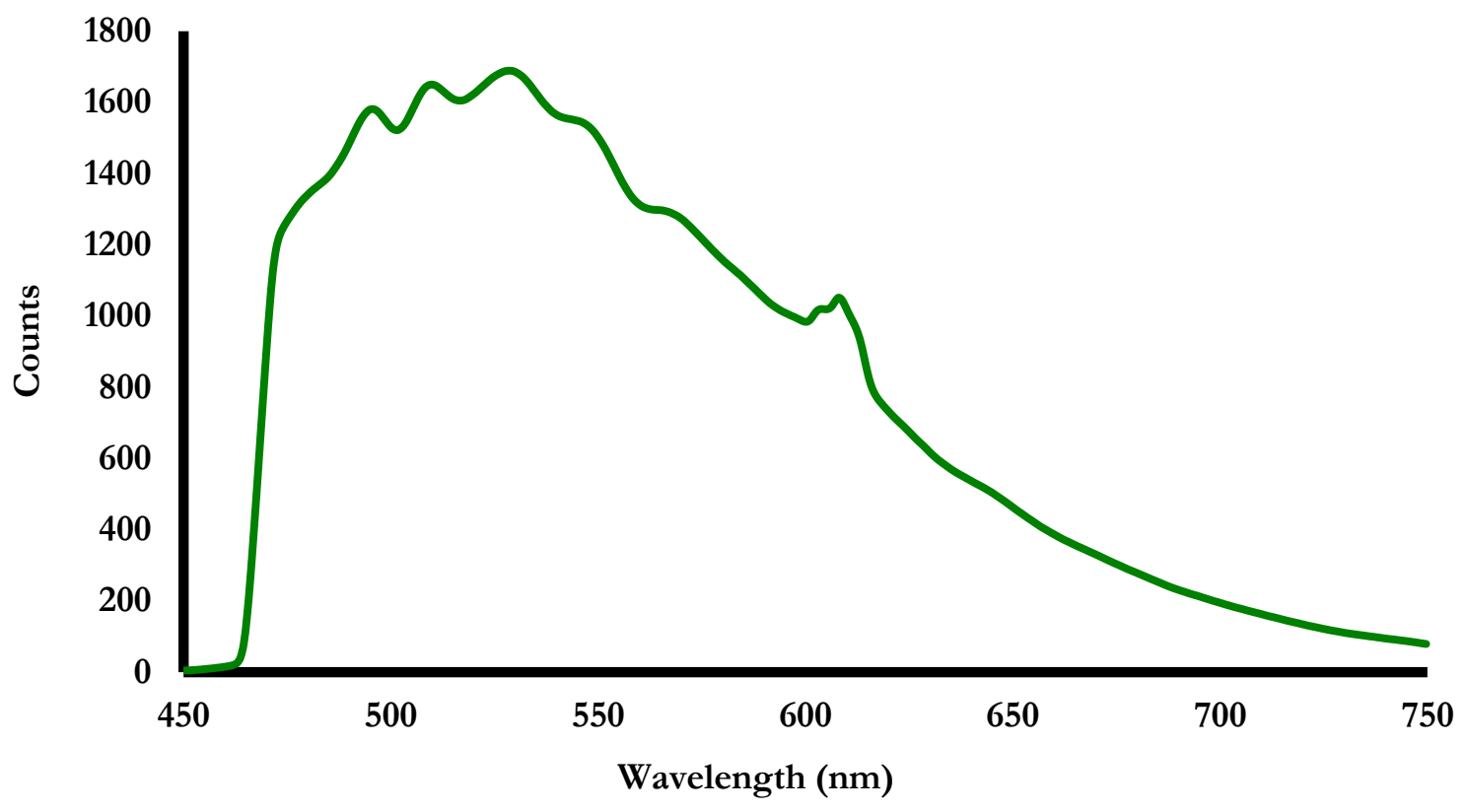


Figure S5. Overlay of ${ }^{249} \mathrm{Cf}(\mathrm{HDPA})_{3}$ doped DPA sample with spectrum acquired from a crystal of ${ }^{249} \mathrm{Cf}(\mathrm{HDPA})_{3}$. A normalization factor has been applied to put the spectra on the same scale.

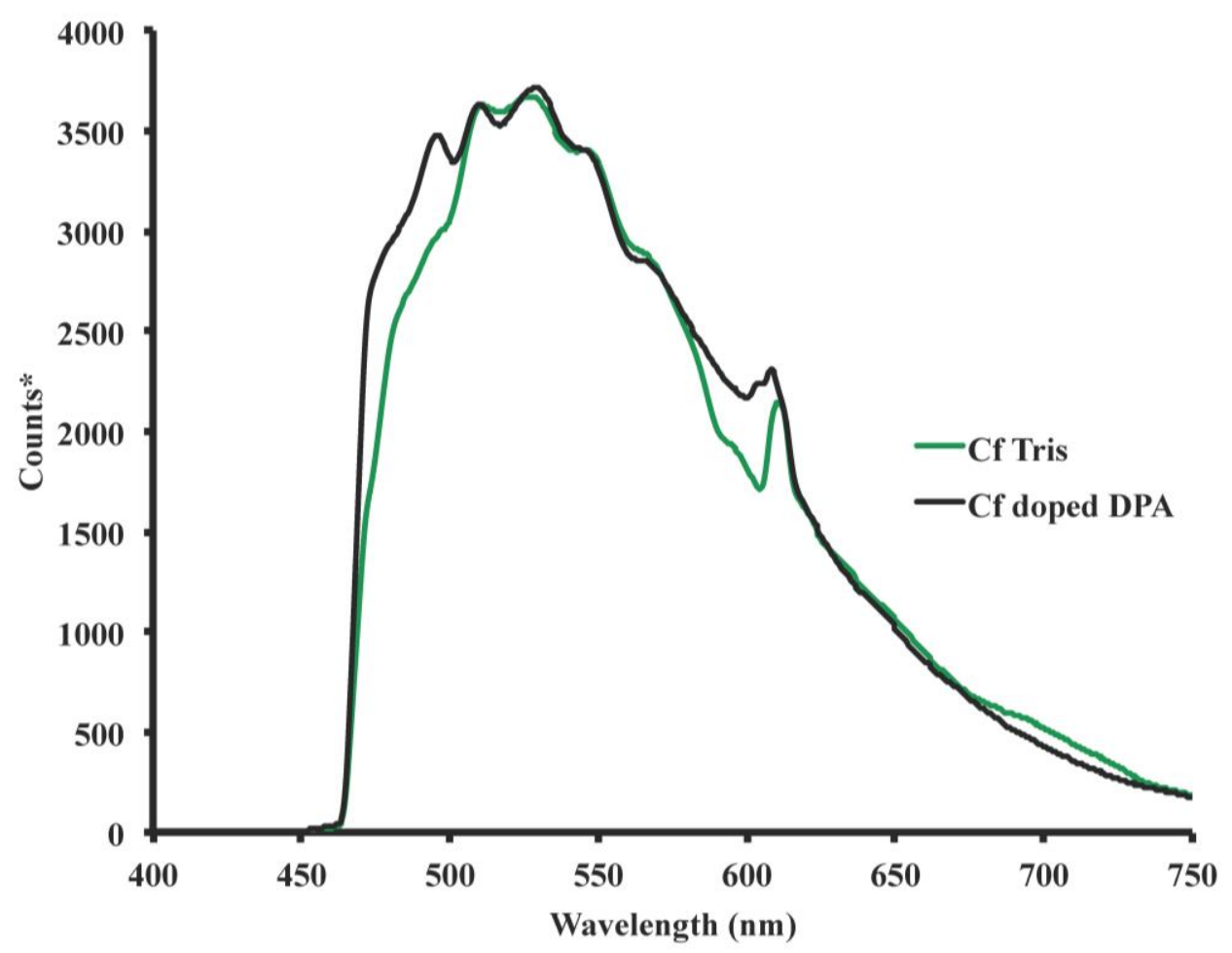

Figure S6. Excitation spectrum of a ${ }^{249} \mathrm{Cf}(\mathrm{HDPA})_{3}$ doped DPA sample from $320 \mathrm{~nm}$ to $410 \mathrm{~nm}$ monitored at $525 \mathrm{~nm}$.

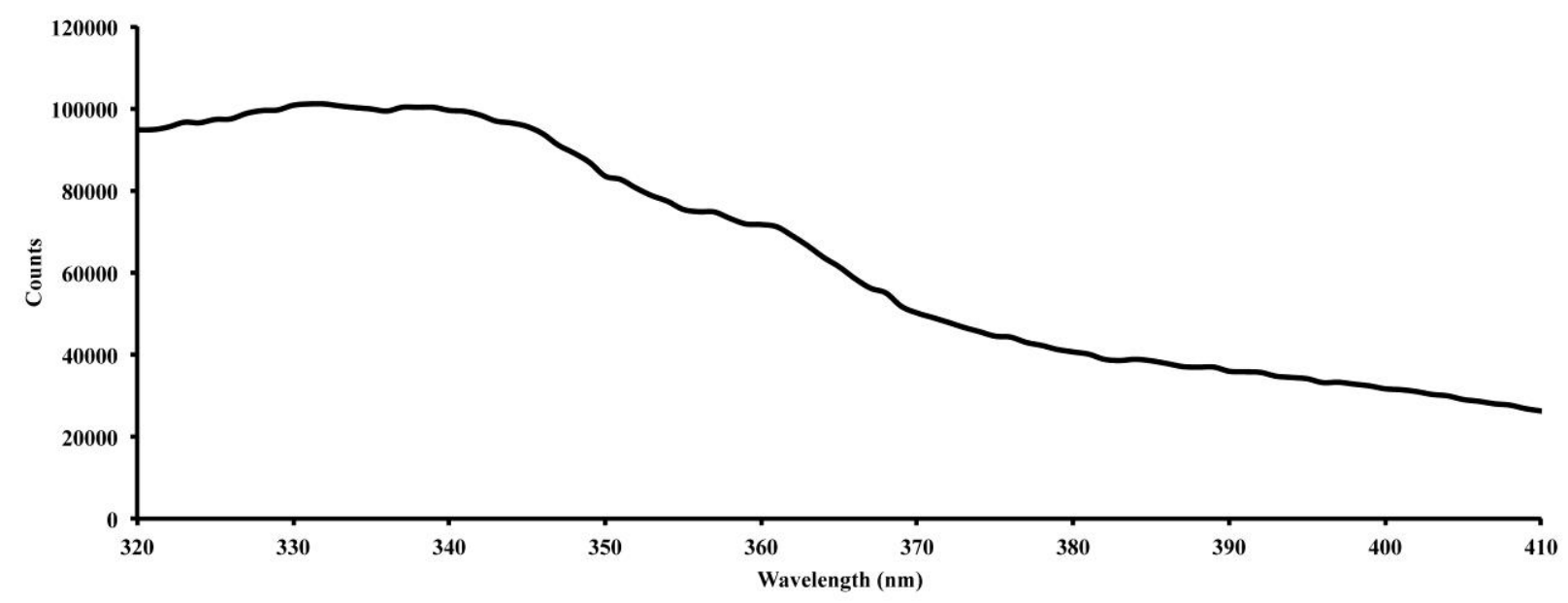


Figure S7. Renderings of the HOMO-2 (left) and LUMO (right) for the $\mathrm{Cf}(\mathrm{HDPA})_{3}$ complex.

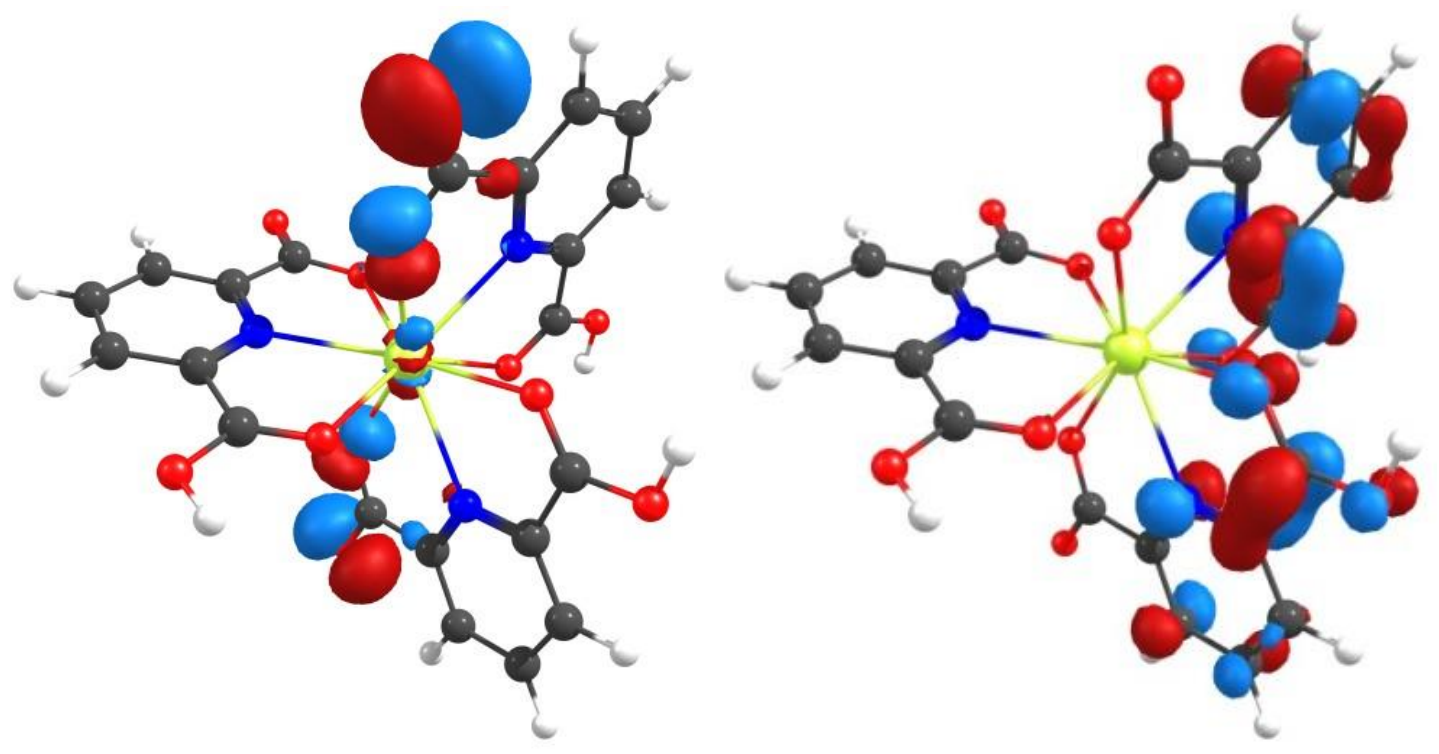

Figure S8. The $700-550 \mathrm{~cm}^{-1}$ region of the DFT predicted IR spectrum of the complex.

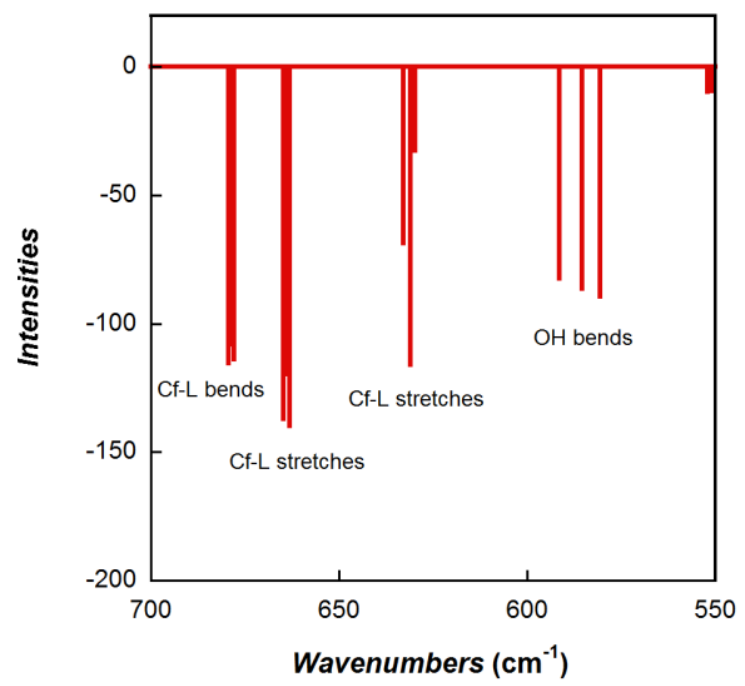


Table S1. Selected crystallographic information for the $\mathrm{Cf}$-doped dipicolinic acid and $\left[\mathrm{Cm}(\mathrm{HDPA})\left(\mathrm{H}_{2} \mathrm{DPA}\right)\left(\mathrm{H}_{2} \mathrm{O}\right)_{2} \mathrm{Cl}\right] \mathrm{Cl} \cdot 2 \mathrm{H}_{2} \mathrm{O}(\mathbf{C m}-\mathbf{2})$.

\begin{tabular}{|c|c|c|c|}
\hline & Compound & DPA & $\mathrm{Cm}-2$ \\
\hline & 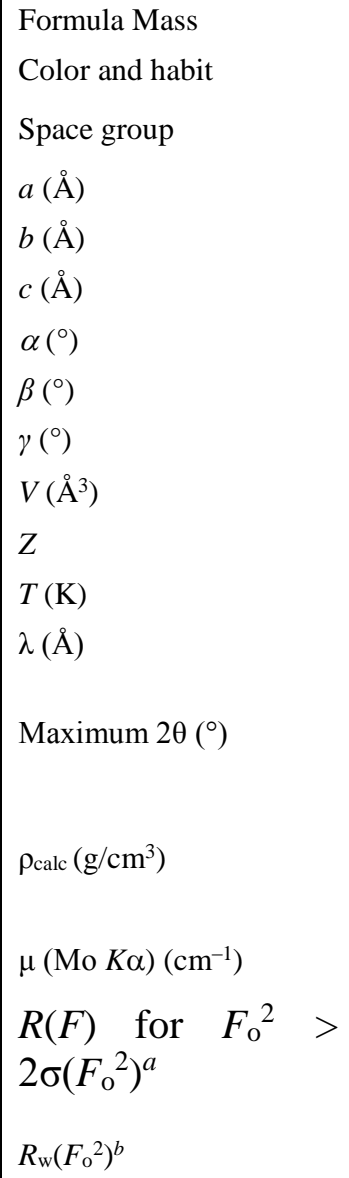 & $\begin{array}{l}167.10 \\
\text { Colorless, Plate } \\
P 21 / \mathrm{m} \\
3.7611(8) \\
16.153(3) \\
5.5595(10) \\
90 \\
93.186(5) \\
90 \\
337.23(11) \\
2 \\
293(2) \\
0.71073 \\
27.517 \\
0.1571 \\
1.626 \\
1.38 \\
0.0543 \\
\end{array}$ & $\begin{array}{l}1465.40 \\
\text { yellow, prism } \\
P \overline{1} \\
7.8840(5) \\
9.8706(6) \\
15.298(1) \\
75.978(1) \\
75.447(1) \\
68.872(1) \\
1059.55(12) \\
1 \\
100(2) \\
0.71073 \\
27.476 \\
0.0286 \\
2.297 \\
41.67 \\
\end{array}$ \\
\hline${ }^{b} R_{\mathrm{w}}\left(F_{\mathrm{o}}^{2}\right)=$ & {$\left[w\left(F_{\mathrm{o}}^{2}-F_{\mathrm{c}}^{2}\right)^{2}\right] / \sum$} & $\left.F_{\mathrm{o}}^{4}\right]^{1 / 2}$ & \\
\hline
\end{tabular}


Table S2. Optimized coordinates for $\mathrm{Cf}(\mathrm{HDPA})_{3}$.

\begin{tabular}{lrrr}
$\mathrm{Cf}$ & -0.073338000 & 0.053564000 & -0.077033000 \\
$\mathrm{O}$ & -0.814669000 & 1.622433000 & -1.646093000 \\
$\mathrm{O}$ & -1.447330000 & -1.213723000 & 1.711966000 \\
$\mathrm{O}$ & -2.440127000 & 2.788372000 & -2.693746000 \\
$\mathrm{O}$ & -3.433509000 & -1.622254000 & 2.687510000 \\
$\mathrm{H}$ & -2.881189000 & -2.208441000 & 3.242815000 \\
$\mathrm{~N}$ & -2.561816000 & 0.496716000 & -0.005840000 \\
$\mathrm{C}$ & -2.036473000 & 1.992314000 & -1.842781000 \\
$\mathrm{C}$ & -3.053628000 & 1.359777000 & -0.896230000 \\
$\mathrm{C}$ & -4.420375000 & 1.660029000 & -0.941145000 \\
$\mathrm{H}$ & -4.779034000 & 2.365171000 & -1.681512000 \\
$\mathrm{C}$ & -5.275554000 & 1.044368000 & -0.030476000 \\
$\mathrm{H}$ & -6.339164000 & 1.258870000 & -0.041510000 \\
$\mathrm{C}$ & -4.752086000 & 0.144542000 & 0.904232000 \\
$\mathrm{H}$ & -5.385248000 & -0.352096000 & 1.629476000 \\
$\mathrm{C}$ & -3.380170000 & -0.097546000 & 0.874222000 \\
$\mathrm{C}$ & -2.661094000 & -1.025624000 & 1.791741000 \\
$\mathrm{O}$ & -0.346538000 & 1.657422000 & 1.659675000 \\
$\mathrm{O}$ & 1.862743000 & -0.055262000 & -1.786575000 \\
$\mathrm{O}$ & 0.291585000 & 3.472345000 & 2.844451000 \\
$\mathrm{O}$ & 3.708196000 & 0.846122000 & -2.706323000 \\
$\mathrm{H}$ & 3.613058000 & 0.079473000 & -3.306706000 \\
$\mathrm{~N}$ & 1.731728000 & 1.875677000 & 0.039033000 \\
$\mathrm{C}$ & 0.423634000 & 2.652505000 & 1.929702000 \\
$\mathrm{C}$ & 1.617880000 & 2.803808000 & 0.990529000 \\
\hline
\end{tabular}




$\begin{array}{lrrr}\mathrm{H} & 2.415095000 & 4.577021000 & 1.897478000 \\ \mathrm{C} & 3.604537000 & 3.912635000 & 0.206708000 \\ \mathrm{H} & 4.336621000 & 4.710855000 & 0.273215000 \\ \mathrm{C} & 3.719298000 & 2.937104000 & -0.789506000 \\ \mathrm{H} & 4.529486000 & 2.952771000 & -1.508459000 \\ \mathrm{C} & 2.753002000 & 1.934212000 & -0.828911000 \\ \mathrm{C} & 2.729762000 & 0.818250000 & -1.814146000 \\ \mathrm{O} & 1.710761000 & -0.589508000 & 1.763819000 \\ \mathrm{O} & -0.988585000 & -1.461733000 & -1.662974000 \\ \mathrm{O} & 3.087505000 & -2.094625000 & 2.716847000 \\ \mathrm{H} & 3.295465000 & -1.330215000 & 3.290549000 \\ \mathrm{O} & -1.124229000 & -3.440046000 & -2.745402000 \\ \mathrm{~N} & 0.849613000 & -2.385053000 & -0.009488000 \\ \mathrm{C} & 2.181964000 & -1.722862000 & 1.821258000 \\ \mathrm{C} & 1.769682000 & -2.797469000 & 0.876229000 \\ \mathrm{C} & 2.270714000 & -4.097518000 & 0.895677000 \\ \mathrm{H} & 3.012907000 & -4.391839000 & 1.627797000 \\ \mathrm{C} & 1.783750000 & -4.999102000 & -0.056314000 \\ \mathrm{H} & 2.149010000 & -6.020745000 & -0.075654000 \\ \mathrm{C} & 0.827508000 & -4.570420000 & -0.972673000 \\ \mathrm{H} & 0.417043000 & -5.229831000 & -1.728087000 \\ \mathrm{C} & 0.379733000 & -3.244926000 & -0.915864000 \\ \mathrm{C} & -0.670851000 & -2.691877000 & -1.873794000\end{array}$

Lowest Energy Frequencies (in cm ${ }^{-1}$ ): 17.5221, 23.7730, 27.4162, 27.7950, 30.5280, 33.3412.

Sum of electronic and thermal Free Energies (in hartrees): $-\underline{2607.697720}$ 